\title{
Effects of Restoration Time on Microbial Diversity in Rhizosphere and Non-Rhizosphere Soil of Bothriochloa ischaemum
}

\author{
Tong Jia ${ }^{1, *}$, Miaowen Cao ${ }^{1,2}$ and Ruihong Wang ${ }^{1}$ \\ 1 Institute of Loess Plateau, Shanxi University, Taiyuan 030006, China; caomw1993@163.com (M.C.); \\ rui_hong_w@163.com (R.W.) \\ 2 Technology Development Department, Shanxi Xinghuacun Fenjiu Group Wine Industry Development Zone \\ Limited by Share Ltd., Fenyang 032205, China \\ * Correspondence: jiatong@sxu.edu.cn; Tel.: +86-155-1369-4458
}

Received: 28 August 2018; Accepted: 28 September 2018; Published: 30 September 2018

check for updates

\begin{abstract}
There is well-documented evidence that shows phytoremediation and restoration methods affect physical and chemical properties, enzyme activities, and microbial communities of soil. In this study, we investigated the response of soil microbial communities to restoration time. We found that arsenic content decreased gradually as restoration progressed. Total carbon $(C)$ in shoots and total nitrogen $(\mathrm{N})$ in roots of $B$. ischaemum both exhibited increasing trends with an increase in restoration time. The transfer factor of chromium was negatively correlated to $C$ in shoots and positively correlated to sulfur in roots. Additionally, the transfer factor of lead had a remarkably positive correlation to the $\mathrm{C} / \mathrm{N}$ ratio of roots. For soil enzymes, total $\mathrm{N}$ in soil was positively correlated to catalase and urease but negatively correlated to sucrose. Moreover, bulk soil bacterial composition was positively correlated to catalase, sucrase and phosphatase while fungal diversity was positively correlated to sucrose. This study found that restoration time plays the most significant role in bacterial and fungal composition and bacterial diversity, but it has no effect on fungal diversity in rhizosphere and non-rhizosphere soil. In addition, the driving factors of microbial composition and diversity varied in rhizosphere and non-rhizosphere soil among the different restoration time treatments.
\end{abstract}

Keywords: Bothriochloa ischaemum; rhizosphere; bacterial diversity; fungal composition; restoration time; soil enzyme activity

\section{Introduction}

Heavy metal soil pollution is one of the most critical issues related to mining processes. Heavy metal pollution in mining areas primarily derives from dust, coal gangue, and acid waste water produced during mining processes. Additionally, these heavy metals enter the soil through several means and pathway, such as wind erosion-derived dust, migration, deposition, and precipitate leaching. The drainage of mine tailings can cause arsenic (As) pollution as well as other highly toxic substances in the surrounding soil, while also decreasing plant mineral elements and soil $\mathrm{pH}$ conditions unsuitable for plant growth [1]. Microbes, soil enzymes and unique microbial groups are the three most important soil components during restoration processes in mining areas, which all play a vital role in nutrient cycling while improving soil fertility and decontamination. Based on plant characteristics that can either tolerate or accumulate certain pollutants, phytoremediation can remedy, absorb, and beneficiate pollutants by means of plants and their co-existing microbial systems. Plant-microbial remediation technology has gained considerable attention in recent years [2-6]. Plants and their associative microbial rhizosphere communities can symbiotically consolidate their survival strategies 
toward restoration, which can influence the form and bioavailability of contaminants as well as promote the absorption of pollutants by plants.

The soil environment supports soil microbial subsistence. Even though various soil nutrient types provide sources of energy for microbial use, the transformation and production of nutrient substrates depend on microbes and soil enzymes. Soil enzymes are important components of the ecosystem production and the core of the soil ecosystem structure and function. They participate in all soil biochemical reactions, promote the transformation of carbon $(\mathrm{C})$, nitrogen $(\mathrm{N})$, phosphorus $(\mathrm{P})$, and other elements for cycling, and encourage energy metabolism and pollutant decontamination [7-9]. In addition, soil enzymes work in conjunction with soil microbes to promote metabolic processes in soil and soil enzyme activity can be used as an activity index of soil quality and an evaluation index of soil fertility [10]. Therefore, the study of soil enzymes can help us to better understand interactions among plants, soil, and microorganisms, as well as reveal the flow of energy and nutrients in the plant-soil-microbial continuum.

Soil enzymes such as urease, sucrose, and catalase are more sensitive, which can reflect the toxic effect of heavy metals on soil microbial activity [11]. As a crucial source of soil enzymes, soil microbes can produce extracellular enzymes and play a critical role in regulating the soil ecosystem by maintaining the stability of the material cycle and purifying soil. Additionally, soil microbes are sensitive to heavy metal pollution and reflect soil quality, which is an important biological index to evaluate soil quality [12]. To date, most research has focused on soil microbial and enzyme activities under heavy metal pollution. Li Wei et al. [13] have reported on the effects Chlorophytum comosum on the quantity of soil microbial and enzyme activity under $\mathrm{Zn}$ contaminated, which found the abundance of soil bacteria, fungi and actinomycetes as well as the activities of catalase, sucrase, urease, and phosphatase in the experimental group were significantly higher than those in the control group. It indicated that $C$. comosum has an obvious remediation effect on soil heavy metal of $\mathrm{Zn}$ contaminated. Gao Yang et al. [14] studied the effect of maize growth on the microbial community structure and the enzyme activity under single and complex pollution of $\mathrm{Cd}$ and $\mathrm{Pb}$, which displayed that planting maize could improve soil respiration intensity under heavy metal pollution and reduce the effect of $\mathrm{Cd}$ and $\mathrm{Pb}$ on phosphatase and urease.

The microbial communities of the rhizosphere are important driving forces and the main participant in biogeochemical cycles of various life-providing elements in terrestrial ecosystems and they also promote the absorption and utilization of plants by converting organic nutrients into inorganic nutrients. Moreover, the rhizosphere provides a place and a medium for microbial metabolism to take place. Therefore, interactions among the rhizosphere, plants, and microorganisms maintain the ecological function of the soil ecosystem [15]. In addition, rhizosphere microorganisms play significant roles in plant growth and development, nutrient acquisition, yields and disease and insect defense mechanisms while photosynthetic products from plants provide both a substrate and energy for rhizosphere microbial subsistence [16]. At the same time, microbial diversity in the rhizosphere is abundant. Many studies have reported that the surface of the plant root system with its high microbial diversity is one of the most complex microbial community collectives on the planet. Moreover, cell density of various microbes that colonize the root surface is much higher than that of plants and the number of genes from rhizosphere microorganisms far exceeds that of plant genes [17]. Plants influence the structure of the rhizosphere microbe community by secreting root exudates. Additionally, there is also a certain degree of dependence and specificity between plants and rhizosphere microorganisms. Conversely, however, structural changes in rhizosphere microbe communities affect plant root exudates, material circulation, energy flow, and information transmission within the soil system, which affects the growth, development and diversity of plant communities $[18,19]$.

Much of the relevant research to date has focused on the characteristics related to the succession of vegetation communities after restoration in mining areas and the effect of different vegetation restoration methods on soil properties, enzyme activities, and microbial communities. It has been reported that soil $\mathrm{C}$ and $\mathrm{N}$ content is significantly affected by different vegetation restoration methods 
and durations [20]. Soil enzyme activities and microbial properties have increasingly been used as indicators of soil quality in the evaluation of reclamation efforts [21,22]. It has been reported that soil enzymes and microbes have been used to assess the success rate of reclamation methods in surface coal mines treated with various restoration methods in the Loess Plateau [23]. However, relatively few studies have been conducted on soil microbes that are more sensitive to ecological restoration and enzyme activities. That being said, a few studies have been conducted on rhizosphere and non-rhizosphere microbial communities in mining areas under heavy metal contamination.

This study was conducted in the eighteenth river tailings of the Northern Copper Mine in Yuanqu County, Shanxi Province, China. In each sub-dam, different vegetation types have established themselves following the commencement of phytoremediation and the subsequent restoration phases. Among these vegetation types, Bothriochloa ischaemum is an edificator within most plant communities [24]. B. ischaemum is a perennial grass species in the grass family (Poaceae), genus Bothriochloa kuntze, and belongs to the thermophilic and mesoxerophyte plant group. In this study, we investigated the response of soil bacterial and fungal communities in rhizosphere and non-rhizosphere soil to restoration time in a copper tailings dam using the denaturing gradient gel electrophoresis (DGGE) technique. We addressed the following questions: (1) What are the characteristics and influencing factors of soil enzyme activities for different restoration times within a heavy metal polluted environment? (2) Do rhizosphere and bulk soil communities differ in different sub-dams? (3) What are the driving factors for rhizosphere and non-rhizosphere soil microbial composition and diversity in sub-dams for different restoration times?

\section{Materials and Methods}

\subsection{Site Description and Soil Sampling}

The eighteenth river tailings of the Northern Copper Mine $\left(35^{\circ} 15^{\prime} \sim 35^{\circ} 17^{\prime} \mathrm{N}, 118^{\circ} 38^{\prime} \sim 111^{\circ} 39^{\prime} \mathrm{E}\right)$ was constructed in 1969 in the southern region of Shanxi Province, China. Currently, the eighteenth river tailings are composed of 14 sub-dams with a stack height of $84 \mathrm{~m}$ and a texture ratio of 1:6 [25]. It is under the influence of a continental monsoon climate with four distinct seasons where the annual mean temperature is $14{ }^{\circ} \mathrm{C}$, annual precipitation is approximately $780 \mathrm{~mm}$, and frost-free days are greater than 200 day/year [26].

In July 2015, we selected five sub-dams (S536, S531, S529, S525, and S523) under different restoration stages $(19,23,27,31$, and 35 years, respectively) for sampling [25]. For each sub-dam, we randomly collected shoot and root samples from $B$. ischaemum in five $1 \mathrm{~m} \times 1 \mathrm{~m}$ sample plots following an S-shaped curve. At the same time, we collected rhizosphere and non-rhizosphere soil samples from each plot. Visible roots and residue were removed prior to homogenizing the soil fraction of each sample. Fresh soil samples were sifted through a $2 \mathrm{~mm}$ sieve and divided into two subsamples. One subsample was stored at $48^{\circ} \mathrm{C}$ to determine physiochemical properties while the other was stored at $20^{\circ} \mathrm{C}$ prior to DNA extraction.

\subsection{Soil Chemical Properties and Enzyme Activities}

Soil $\mathrm{pH}$ was measured after shaking in a soil-water (1:2.5 m/v) suspension for $30 \mathrm{~min}$. Soil water content (SWC) was measured gravimetrically. Soil particle size (PS) was measured using the Mastersizer 3000 laser diffraction particle size analyzer (Malvern Panalytical Ltd., Malvern, UK). Total plant and soil C, N, and sulfur (S) content was measured by using an elemental analyzer (vario EL/MACRO cube, Elementar, Hanau, Germany). Nitrate nitrogen $\left(\mathrm{NO}_{3}{ }^{-}-\mathrm{N}\right)$, ammonium nitrogen $\left(\mathrm{NH}_{4}{ }^{+}-\mathrm{N}\right)$ and nitrite nitrogen $\left(\mathrm{NO}_{2}{ }^{-}-\mathrm{N}\right)$ were determined by using an automated discrete analyzer (CleverChem 380, DeChem-Tech. GmbH, Hamburg, Germany). Heavy metal (As, Cd, copper (Cu), $\mathrm{Pb}$ and $\mathrm{Zn}$ ) sample concentrations were measured using the ICP-AES (iCAP 6000, Thermo Fisher, Cambridge, UK). Additionally, soil sucrase was measured by using 3,5-Dinitrosalicylic acid colorimetry. Urease was measured using phenol-sodium hypochlorite calorimetry. Catalase was measured by using 
potassium permanganate titration, and phosphatase was measured by using the disodium phenyl phosphate calorimetric method [27].

\subsection{DNA Extraction, Polymerase Chain Reaction and Denaturing Gradient Gel Electrophoresis}

Total soil DNA was extracted using the E.Z.N.A. Soil DNA Kit (Omega Bio-tek, Inc., Norcross, GA, USA). The structure of the bacterial and fungal communities was evaluated using the DGGE technique as follows: Fragments of $16 \mathrm{~S} r R N A$ genes (the V3 region) were amplified by a polymerase chain reaction (PCR) using primers 341F (5'-CGC CCG CCG CGC GCG GCG GGC GGG GCG GGG GCA CGG GGG GCC TAC GGG AGG CAG CAG-3') and 534R (5'-ATT ACC GCG GCT GCT GG-3'). Fragments of $18 S r R N A$ genes (the V4 region) were amplified by PCR using the primers FUNG-GC (5'-CGC CCG CCG CGC CCC GCG CCC GGC CCG CCG CCC CCG CCC CAT TCC CCG TTA CCC GTT G-3') and NS1 (5'-GTA GTCA TAT GCT TGT CTC-3'). The DGGE runs were performed using a DCode system (GelDoc XR, Biorad, Hercules, CA, USA).

\subsection{Statistical Analysis}

Significant differences between sub-dam variables were analyzed by one-way analysis of variance (ANOVA) and Duncan's new multiple range test. The Pearson correlation coefficient was used to analyze the relationship between soil physicochemical properties and enzyme activities. Furthermore, DGGE image analysis of the band profiles were carried out by using Quantity One 1-D Analysis software version 4.6.2 (Bio-Rad Laboratories, Inc., Hercules, CA, USA), which detects bands and quantifies the relative DNA concentration. The number of distinct DGGE bands was imported into SPSS version 20.0 (IBM, Chicago, IL, USA) to calculate the Shannon-Wiener index $\left(H^{\prime}\right)$, the Margalef's richness index $(d M a)$, an evenness index $(E n)$, species richness $(S)$, and the Simpson's Diversity Index (D) [28]. The Mantel test was used to test relationships between microbial composition and diversity, soil and root variables, and restoration years and transfer factors. Statistical analyses were performed using the Canoco 5.0and Sigma Plot 12.5.

\section{Results}

\subsection{Plant and Soil Characteristics of B. ischaemum for the Different Restoration Times}

With the exception of $\mathrm{NH}_{4}{ }^{+}-\mathrm{N}$, we observed significant differences in soil physical and chemical properties among the different restoration times (Table 1). $\mathrm{NH}_{4}{ }^{+}-\mathrm{N}$ showed a decreasing trend with an increase in recovery time and its content was the highest in the S529 sub-dam. As restoration time increased, we found a significant difference in As content (Table 2). Moreover, As content gradually decreased as recovery time increased and, between the recovery times investigated, the S536 sub-dam had the highest As content overall $(25.44 \mathrm{mg} / \mathrm{L})$.

This study observed increasing trends in total stem $\mathrm{C}$ content and total root $\mathrm{N}$ content of B. ischaemum with an increase in restoration time (Figure 1). Results from the Mantel test showed that the physiological characteristics of aboveground plant components $(\mathrm{r}=0.1396, p=0.046)$ and roots $(\mathrm{r}=0.1394, p=0.032)$ of $B$. ischaemum were significantly correlated to the restoration time.

There were no significant changes in heavy metal transfer factors among the different restoration times (Table 2). Correlation analysis showed that TF-Cr was significantly negatively correlated to the total $\mathrm{C}$ content in stems and positively correlated to the total $\mathrm{S}$ content in roots. Additionally, TF- $\mathrm{Pb}$ was significantly positively correlated to the $\mathrm{C} / \mathrm{N}$ ratio (Table 3 ). 

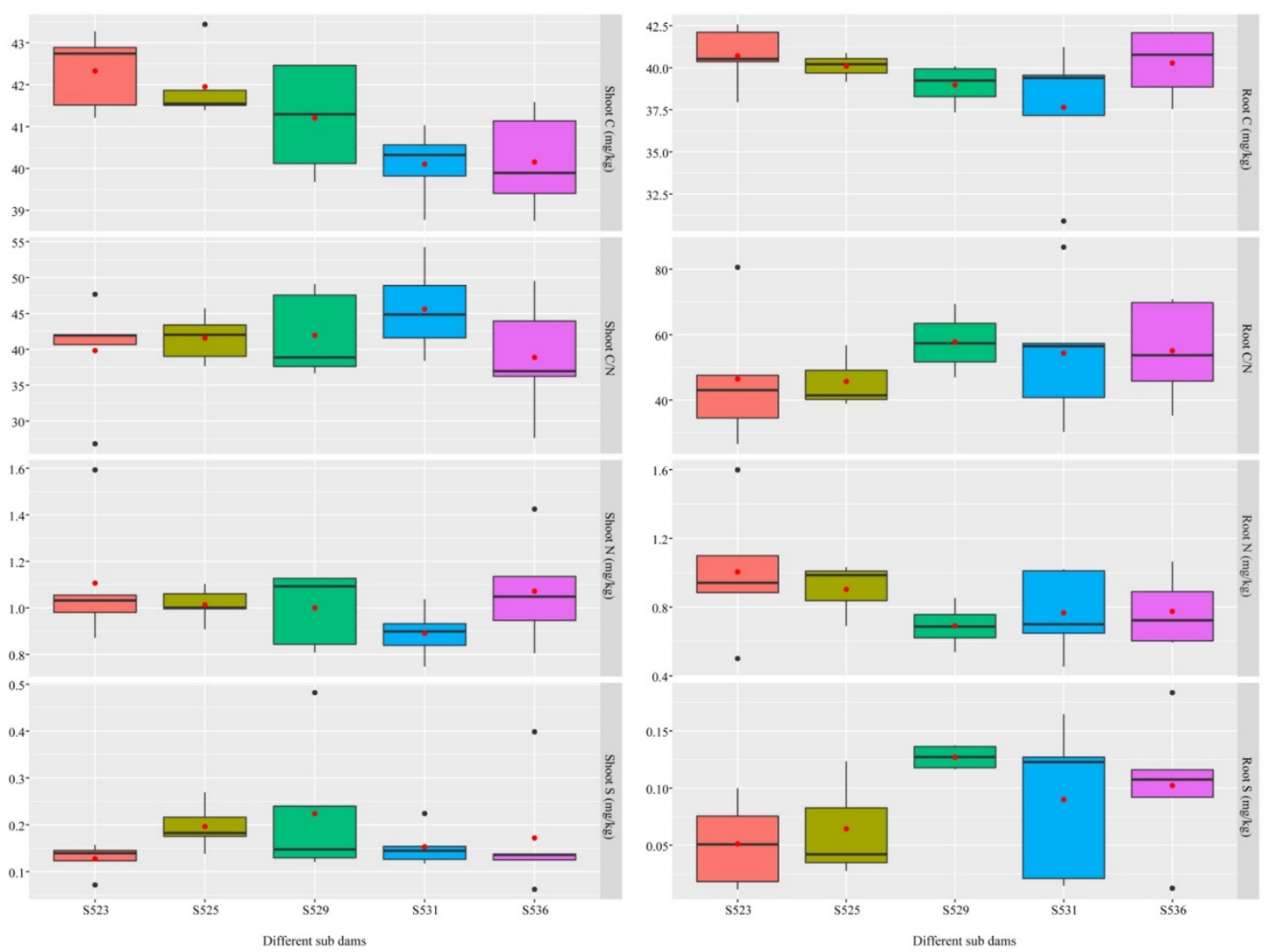

Figure 1. Total nitrogen $(\mathrm{N})$, total carbon $(\mathrm{C})$, ratio of carbon and nitrogen $(\mathrm{C} / \mathrm{N})$, and total sulphur (S) in shoot and root of B. ischaemum. Different-colored boxes represent different sub-dams (red, S523, olivine, S525, green, S529, blue, S531, pink, S536).

\subsection{Correlation betweenPlant Physicochemical Properties and Soil Characteristics}

The Mantel test showed that enzyme activities were significantly correlated to $C$ content in roots (Mantel statistic: $\mathrm{r}=0.5796, p=0.007)$ and $\mathrm{Zn}$ content in soil $(\mathrm{r}=0.4012, p=0.017)$. Additionally, soil total nitrogen was highly significantly and positively correlated to catalase and urease, but highly significant negatively correlated to sucrase (Table 3). However, we found no significant correlations between phosphatase and soil physicochemical properties, but we observed a significant negative correlation between phosphatase and total C and S in B. ischaemum (Table 3).

Furthermore, arsenic was significantly negatively correlated to total $\mathrm{N}$ and $\mathrm{C}$ in soil, positive correlations between soil C/N and As and Cu were also observed. Similarly, we found a significant positive correlation between SWC and $\mathrm{Cu}$ (Table 3), which indicated that high SWC content is not beneficial to $\mathrm{Cu}$ absorption. Moreover, there was a positively correlation between $\mathrm{Zn}$ and soil $\mathrm{NO}_{3}{ }^{-} \mathrm{N}$ and a negative correlation between $\mathrm{Zn}$ in soil and $\mathrm{C}$ in roots (Table 3). One possible reason for this is that $\mathrm{Zn}$ is a necessary element for plant growth and the storage of $\mathrm{C}$ in roots is conductive to $\mathrm{Zn}$ absorption from the soil. Additionally, we found a significant negative correlation between $\mathrm{N}$ in stems and $\mathrm{Pb}$ in soil (Table 3), which indicated that an increase in plant nutrition could lead to a reduction in $\mathrm{Pb}$ content in soil. 
Table 1. Soil chemical properties of the different sub-dams (Mean \pm Standard error). Significant differences between sites (Duncan test, $p<0.05)$ are denoted with letters $(a>b>c)$.

\begin{tabular}{|c|c|c|c|c|c|c|c|c|c|c|c|}
\hline & $\mathrm{NH}_{4}{ }^{+}-\mathrm{N} \mathrm{mg} / \mathrm{kg}$ & $\mathrm{NO}_{3}{ }^{+}-\mathrm{N} \mathrm{mg} / \mathrm{kg}$ & $\mathrm{NO}_{2}{ }^{+}-\mathrm{N} \mathrm{mg} / \mathrm{kg}$ & Olsen-P mg/kg & $\mathrm{N} \mathrm{mg/kg}$ & $\mathrm{C} \mathrm{mg} / \mathrm{kg}$ & $\mathrm{C} / \mathrm{N}$ & $5 \mathrm{mg} / \mathrm{kg}$ & SWC \% & $\mathrm{pH}$ & PS $\mu \mathrm{m}$ \\
\hline S523 & $4.566 \pm 0.487 \mathrm{bc}$ & $5.160 \pm 0.513$ & $0.350 \pm 0.028$ & $6.218 \pm 1.339$ & $0.053 \pm 0.005$ & $1.089 \pm 0.053$ & $21.092 \pm 1.563$ & $0.068 \pm 0.011$ & $2.222 \pm 0.451$ & $7.987 \pm 0.075$ & $44.98 \pm 4.717$ \\
\hline S525 & $3.974 \pm 1.102 c$ & $82 \pm 0.280$ & $68 \pm 0.045$ & $5.108 \pm 1.290$ & $0.045 \pm 0.003$ & $1.199 \pm 0.102$ & $26.789 \pm 1.717$ & $0.062 \pm 0.007$ & $1.798 \pm 0.552$ & $7.881 \pm 0.074$ & $42.60 \pm 1.799$ \\
\hline S529 & $7.664 \pm 1.318 a$ & $5.276 \pm 0.7$ & $38 \pm 0.041$ & $13.428 \pm 5.870$ & $0.049 \pm 0.007$ & $1.061 \pm 0.064$ & $23.191 \pm 2.592$ & $0.058 \pm 0.007$ & $1.378 \pm 0.292$ & $8.052 \pm 0.100$ & $42.00 \pm 3.933$ \\
\hline S531 & $6.028 \pm 0.602 \mathrm{abc}$ & $6.648 \pm 1.497$ & $0.330 \pm 0.065$ & $8.682 \pm 1.900$ & $0.042 \pm 0.006$ & $0.948 \pm 0.054$ & $24.279 \pm 3.409$ & $0.052 \pm 0.004$ & $1.475 \pm 0.506$ & $8.111 \pm 0.028$ & $40.66 \pm 2.410$ \\
\hline $\begin{array}{l}\mathrm{S} 536 \\
\mathrm{~S}\end{array}$ & $7.086 \pm 0.560 \mathrm{ab}$ & $5.338 \pm 0.744$ & $0.350 \pm 0.054$ & $7.970 \pm 0.540$ & $0.041 \pm 0.005$ & $0.907 \pm 0.047$ & $23.349 \pm 2.031$ & $0.046 \pm 0.001$ & $1.487 \pm 0.391$ & $8.023 \pm 0.084$ & $46.66 \pm 4.829$ \\
\hline
\end{tabular}

Abbreviations mean ammonium nitrogen $\left(\mathrm{NH}_{4}{ }^{-} \mathrm{N}\right)$, nitrate nitrogen $\left(\mathrm{NO}_{3}{ }^{-}-\mathrm{N}\right)$, nitrite nitrogen $\left(\mathrm{NO}_{2}{ }^{-}-\mathrm{N}\right)$, total nitrogen $(\mathrm{N})$, total carbon $(\mathrm{C})$, total sulfur $(\mathrm{S})$, the ratio of carbon and nitrogen $(\mathrm{C} / \mathrm{N})$, soil water content (SWC), and average particle size (PS).

Table 2. Soil heavy metals of the different sub-dams and transfer factors of different heavy metals in B. ischaemum (Mean \pm Standard error). The different case letters $(\mathrm{a}>\mathrm{b}>\mathrm{c})$ indicate that the means are significantly different among reclaimed scenario $(p<0.05)$ with the Duncan test.

\begin{tabular}{|c|c|c|c|c|c|c|c|c|c|c|}
\hline & As ppm & Cd ppm & Cu ppm & $\mathrm{Pb}$ ppm & $\mathrm{Zn} \mathrm{ppm}$ & TF-Cd & TF-Cr & TF-Cu & TF-Pb & TF-Zn \\
\hline S523 & $10.318 \pm 2.783 \mathrm{~b}$ & $6.798 \pm 0.620$ & $366.445 \pm 20.368$ & $258.116 \pm 24.396$ & $81.005 \pm 8.800$ & $0.726 \pm 0.169$ & $0.201 \pm 0.065$ & $0.474 \pm 0.107$ & $1.530 \pm 0.654$ & $1.289 \pm 0.285$ \\
\hline S525 & $10.843 \pm 2.180 \mathrm{~b}$ & $7.258 \pm 0.747$ & $379.141 \pm 30.697$ & $250.481 \pm 36.774$ & $81.040 \pm 5.049$ & $0.426 \pm 0.173$ & $0.131 \pm 0.104$ & $0.289 \pm 0.084$ & $0.830 \pm 0.159$ & $0.743 \pm 0.286$ \\
\hline S529 & $13.183 \pm 3.013 b$ & $7.469 \pm 0.382$ & $324.415 \pm 17.770$ & $277.673 \pm 29.442$ & $85.061 \pm 5.447$ & $0.664 \pm 0.092$ & $0.449 \pm 0.126$ & $0.514 \pm 0.096$ & $1.177 \pm 0.169$ & $1.045 \pm 0.168$ \\
\hline S531 & $12.190 \pm 5.102 \mathrm{~b}$ & $7.111 \pm 1.159$ & $326.789 \pm 34.125$ & $261.731 \pm 19.734$ & $87.296 \pm 11.009$ & $0.612 \pm 0.142$ & $0.410 \pm 0.175$ & $0.491 \pm 0.158$ & $1.100 \pm 0.183$ & $0.992 \pm 0.272$ \\
\hline S536 & $25.440 \pm 3.003 a$ & $6.309 \pm 0.831$ & $352.808 \pm 41.025$ & $224.320 \pm 33.932$ & $69.542 \pm 6.377$ & $0.576 \pm 0.052$ & $0.481 \pm 0.130$ & $0.659 \pm 0.131$ & $1.036 \pm 0.265$ & $0.876 \pm 0.087$ \\
\hline
\end{tabular}

Table 3. The Pearson correlations between chemical properties of soil, root and shoot, soil enzyme, heavy metals and transfer factors in the copper tailings dam.

\begin{tabular}{|c|c|c|c|c|c|c|c|c|c|c|c|c|c|c|c|}
\hline & & \multicolumn{4}{|c|}{ Soil Enzyme Activity } & \multicolumn{5}{|c|}{ Soil Heavy Metals } & \multicolumn{5}{|c|}{ Transfer Factors } \\
\hline & & Catalase & Urease & Sucrase & Phosphatase & As & $\mathrm{Cd}$ & $\mathrm{Cu}$ & $\mathrm{Pb}$ & $\mathrm{Zn}$ & TF-Cd & TF-Cr & TF-Cu & TF-Pb & TF-Zn \\
\hline \multirow{11}{*}{ Soil } & $\mathrm{NH}_{4}{ }^{+}-\mathrm{N}$ & 0.036 & 0.224 & 0.157 & -0.055 & 0.232 & -0.088 & -0.250 & 0.025 & 0.022 & -0.057 & 0.261 & 0.095 & -0.158 & -0.167 \\
\hline & $\mathrm{NO}_{3}{ }^{+}-\mathrm{N}$ & 0.232 & 0.209 & -0.277 & 0.269 & -0.368 & -0.286 & -0.282 & -0.005 & 0.400 * & -0.128 & 0.108 & 0.166 & -0.292 & -0.231 \\
\hline & $\mathrm{NO}_{2}^{+}-\mathrm{N}$ & $\begin{array}{l}0.252 \\
-0.011\end{array}$ & $\begin{array}{l}0.089 \\
-0.083\end{array}$ & $\begin{array}{l}-0.27 \\
0.07\end{array}$ & $\begin{array}{l}0.269 \\
-0.133\end{array}$ & $\begin{array}{c}-0.000 \\
0.191\end{array}$ & $\begin{array}{l}-0.200 \\
-0.147\end{array}$ & $\begin{array}{l}-0.282 \\
0.280\end{array}$ & $\begin{array}{l}-0.003 \\
-0.269\end{array}$ & $\begin{array}{l}0.400 \\
-0.286\end{array}$ & $\begin{array}{l}-0.118 \\
-0.113\end{array}$ & $\begin{array}{l}0.100 \\
-0.204\end{array}$ & $\begin{array}{l}.1 .060 \\
0.082\end{array}$ & $\begin{array}{c}-0.222 \\
0.020\end{array}$ & $\begin{array}{l}-0.201 \\
0.067\end{array}$ \\
\hline & Olsen-P & -0.003 & -0.02 & -0.153 & 0.017 & 0.114 & 0.113 & -0.174 & 0.162 & 0.071 & 0.113 & 0.354 & 0.354 & -0.016 & -0.083 \\
\hline & $\mathrm{N}$ & 0.722 ** & $0.695^{* *}$ & $-0.650^{* *}$ & 0.228 & $-0.652 * *$ & -0.137 & -0.323 & 0.147 & 0.316 & -0.021 & -0.079 & 0.029 & 0.013 & 0.212 \\
\hline & C & 0.327 & 0.29 & -0.199 & -0.023 & -0.494 * & 0.167 & 0.238 & 0.005 & 0.200 & 0.125 & -0.019 & 0.042 & 0.229 & 0.384 \\
\hline & $\mathrm{C} / \mathrm{N}$ & $-0.581 * *$ & $-0.530 * *$ & 0.668 ** & -0.286 & $0.425 *$ & 0.324 & 0.580 ** & -0.112 & -0.263 & 0.125 & 0.125 & -0.019 & 0.140 & 0.101 \\
\hline & $\mathrm{S}$ & 0.083 & 0.195 & -0.335 & 0.010 & -0.202 & 0.023 & 0.231 & -0.100 & 0.142 & 0.346 & 0.002 & 0.284 & 0.682 ** & 0.376 \\
\hline & SWC & $\begin{array}{l}0.003 \\
-0.036\end{array}$ & $\begin{array}{l}0.195 \\
-0.232\end{array}$ & $\begin{array}{l}-0.030 \\
0.237\end{array}$ & $\begin{array}{l}0.010 \\
-0.164\end{array}$ & $\begin{array}{l}-0.124 \\
0.124\end{array}$ & $\begin{array}{l}0.020 \\
-0.043\end{array}$ & $0.449 *$ & $\begin{array}{l}-0.134 \\
-0.134\end{array}$ & $\begin{array}{l}0.142 \\
-0.159\end{array}$ & $0.474^{*}$ & 0.141 & $\begin{array}{l}0.204 \\
0.004\end{array}$ & $\begin{array}{l}0.002 \\
0.118\end{array}$ & 0.167 \\
\hline & $\begin{array}{c}\mathrm{SWC} \\
\mathrm{pH}\end{array}$ & $\begin{array}{l}-0.036 \\
-0.002\end{array}$ & $\begin{array}{c}-0.292 \\
0.297\end{array}$ & $\begin{array}{r}0.237 \\
-0.041\end{array}$ & $\begin{array}{l}-0.164 \\
0.255\end{array}$ & $\begin{array}{l}0.124 \\
0.043\end{array}$ & $\begin{array}{l}-0.043 \\
0.298\end{array}$ & $\begin{array}{l}0.449 \\
-0.208\end{array}$ & $\begin{array}{l}-0.1 .144 \\
-0.112\end{array}$ & $\begin{array}{c}-0.1599 \\
0.013\end{array}$ & $\begin{array}{l}0.44^{4} \\
-0.190\end{array}$ & $\begin{array}{l}0.141 \\
-0.084\end{array}$ & $\begin{array}{c}0.004 \\
-0.231\end{array}$ & $\begin{array}{l}0.118 \\
0.004\end{array}$ & $\begin{array}{l}0.167 \\
0.277\end{array}$ \\
\hline & PS & -0.309 & -0.256 & 0.167 & -0.142 & 0.385 & -0.229 & 0.199 & 0.091 & -0.028 & -0.180 & -0.182 & -0.068 & $\begin{array}{l}-0.103 \\
-\end{array}$ & -0.285 \\
\hline \multirow{4}{*}{ Shoot } & $\mathrm{N}$ & -0.088 & -0.368 & 0.227 & -0.218 & 0.274 & 0.012 & 0.232 & $-0.476^{*}$ & -0.209 & 0.363 & -0.026 & -0.163 & -0.082 & -0.092 \\
\hline & C & 0.150 & -0.079 & -0.207 & -0.204 & -0.247 & -0.114 & 0.134 & 0.084 & -0.120 & -0.092 & -0.603 ** & -0.337 & -0.120 & -0.135 \\
\hline & $\mathrm{C} / \mathrm{N}$ & 0.173 & 0.430 * & -0.295 & 0.166 & -0.344 & -0.109 & -0.321 & $0.535^{* *}$ & 0.167 & -0.308 & -0.093 & 0.129 & 0.078 & 0.063 \\
\hline & $\mathrm{S}$ & 0.028 & 0.348 & -0.158 & -0.119 & -0.322 & 0.066 & -0.092 & 0.139 & 0.358 & -0.161 & 0.145 & 0.008 & 0.080 & 0.125 \\
\hline \multirow{4}{*}{ Root } & $\mathrm{N}$ & 0.307 & -0.127 & -0.021 & 0.162 & -0.211 & -0.018 & -0.137 & -0.082 & 0.059 & 0.266 & -0.066 & -0.170 & -0.337 & -0.205 \\
\hline & $\mathrm{C}$ & 0.140 & -0.191 & -0.230 & $-0.628^{* *}$ & 0.192 & -0.263 & 0.276 & 0.078 & -0.475 * & 0.353 & 0.097 & 0.422 & 0.164 & 0.156 \\
\hline & $\mathrm{C} / \mathrm{N}$ & -0.294 & 0.08 & -0.076 & -0.289 & 0.223 & -0.061 & 0.189 & 0.114 & -0.201 & -0.076 & 0.027 & 0.242 & 0.501 * & 0.309 \\
\hline & $\mathrm{S}$ & $\begin{array}{l}-0.249 \\
-0.406\end{array}$ & $\begin{array}{c}0.08 \\
-0.207\end{array}$ & $\begin{array}{c}-0.006 \\
0.137\end{array}$ & $-0.446^{*}$ & 0.330 & 0.075 & 0.170 & -0.139 & -0.122 & 0.248 & 0.538 ** & 0.335 & 0.187 & 0.069 \\
\hline
\end{tabular}

Abbreviations: $\mathrm{NH}_{4}{ }^{+}-\mathrm{N}$, ammonium nitrogen, $\mathrm{NO}_{3}{ }^{-}-\mathrm{N}$, nitrate nitrogen, $\mathrm{NO}_{2}{ }^{-}-\mathrm{N}$, nitrite nitrogen, $\mathrm{N}$, total nitrogen, $\mathrm{C}$, total carbon, $\mathrm{S}$, total sulfur, $\mathrm{C} / \mathrm{N}$, the ratio of carbon and nitrogen,

SWC, soil water content, and PS, average particle size. ${ }^{* *}$ Correlation is significant at the 0.01 level (2-tailed). ${ }^{*}$ Correlation is significant at the 0.05 level (2-tailed) 


\subsection{Effects of Restoration Time and the Rhizosphere on Microbial Diversity and Gene Abundance}

Restoration time had a significant impact on the diversity and gene abundance of bacteria and fungi while the rhizosphere mainly affected the diversity of fungi as well as the gene abundance of bacteria and fungi. The interaction between restoration time and the rhizosphere had a marked impact on the bacterial diversity but not on fungal diversity (Table 4).

Table 4. Two-way ANOVA of microbial diversity and microbial gene abundances of rhizosphere and non-rhizosphere soil in different sub-dams.

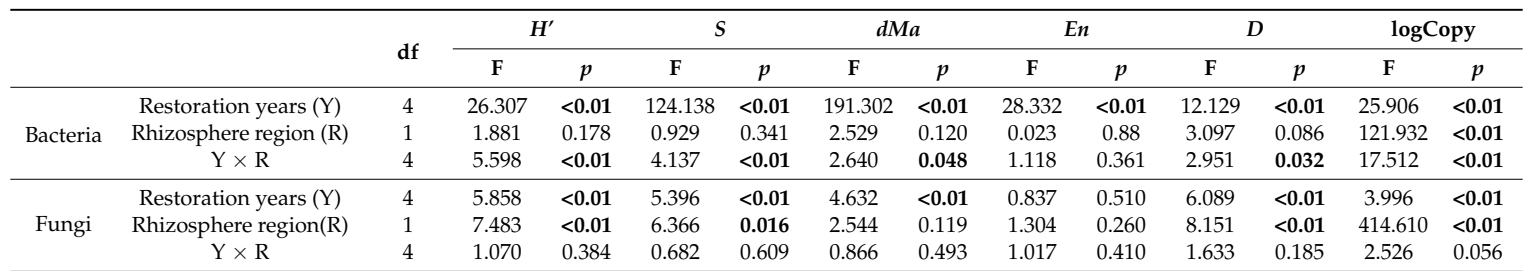

Abbreviations: Shannon-Wiener index $\left(H^{\prime}\right)$, Species richness $(S)$, Margalef $\left(d_{M a}\right)$, Evenness $\left(E_{n}\right)$ and Simpson index $(D)$, ratio of bacteria and fungi gene copies $(\mathrm{B} / \mathrm{F})$. Significant $p$-values are in bold print.

This study found highly and significantly different gene copy numbers between bacteria in rhizosphere and fungi in non-rhizosphere soil (Figure 2). In addition, the gene copy numbers of rhizosphere bacteria in the S525 and S529 sub-dams were significantly higher than those in the other three sub-dams. As shown in Figure 2, the numbers of fungal copies in non-rhizosphere soil of the S525 and S536 sub-dams were significantly higher than those in the other sub-dams.

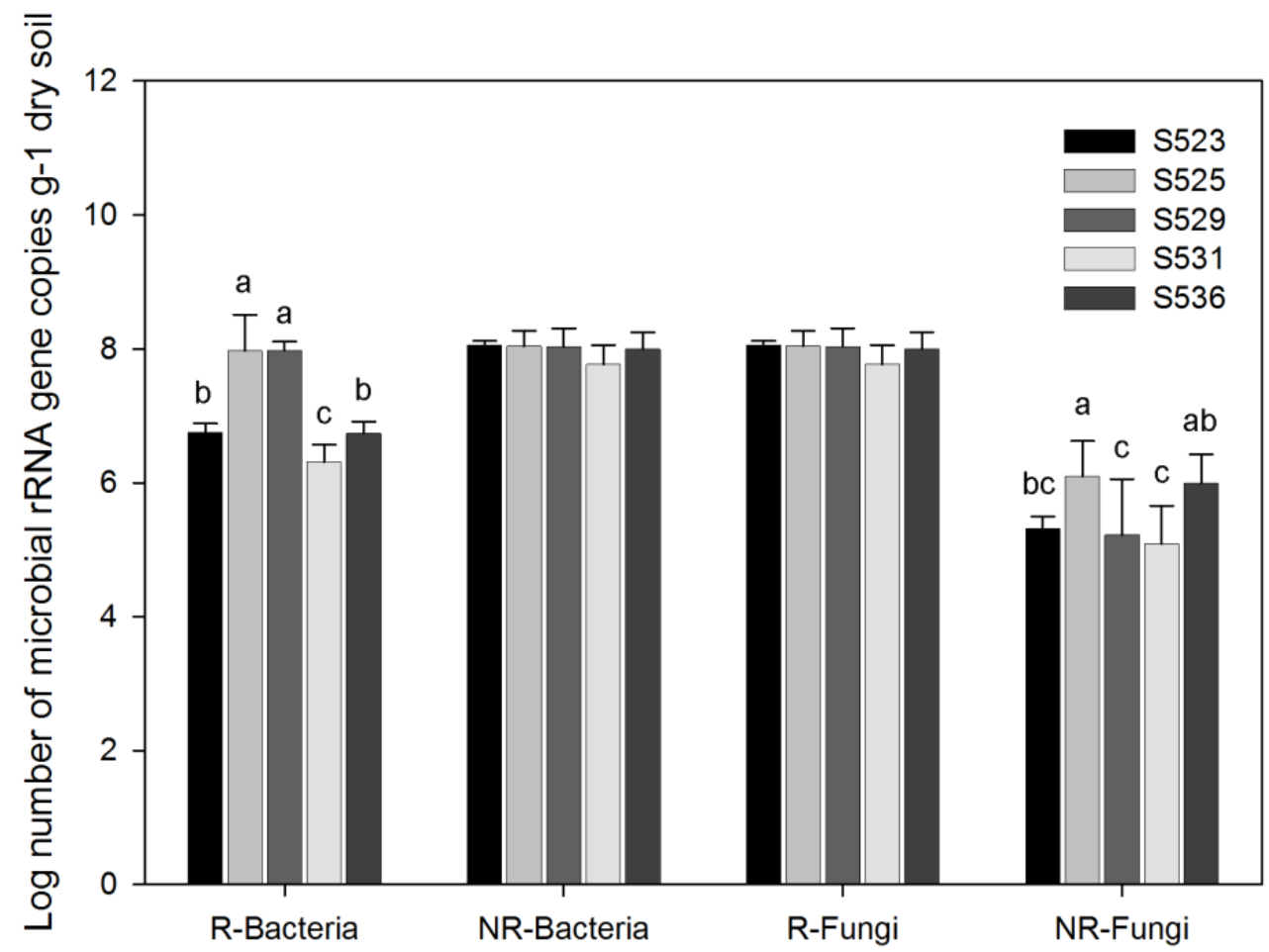

Figure 2. Abundance of rhizosphere (R) and non-rhizosphere (NR) soil bacteria and fungi $r R N A$ genes in different sub-dams. Points show the means of five replicates, and vertical bars show standard errors. The different letters $(\mathrm{a}, \mathrm{b}$ and $\mathrm{c}$ ) indicate that the means are significantly different among restored sub-dams $(p<0.05)$ with the Duncan test.

The ratio of fungi to bacteria (F/B) is shown in Figure 3. Among the different restoration years (times), we found a significant difference in the F/B ratio in the rhizosphere. Moreover, the F/B ratio in 
the rhizosphere of the S531 sub-dam was significantly higher than those of the S525 and S529 sub-dams. Additionally, the F/B ratio of non-rhizosphere soil microbes in the S525 sub-dam was significantly higher than those of the S523, S529, and S531 sub-dams (Figure 3).

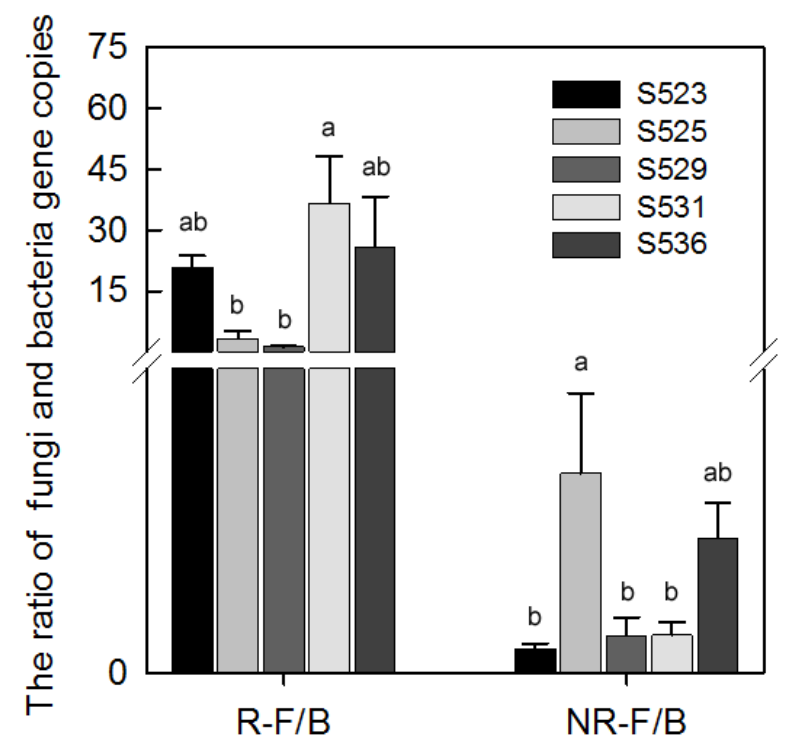

Figure 3. The ratio of bacteria and fungi gene copies (B/F) of rhizosphere (R) and non-rhizosphere (NR) soil in different sub-dams. The different letters $(a, b$ and $c)$ indicate that the means are significantly different among restored sub-dams $(p<0.05)$ with the Duncan test.

\subsection{Relationship between Soil Enzyme Activity and Microbial Diversity}

Enzyme activity was significantly correlated to bacterial composition in the rhizosphere $(r=0.2016$, $p=0.029)$ and non-rhizosphere $(\mathrm{r}=0.3603, p=0.001)$ according to results from the Mantel test. Among these, the composition and diversity of bacteria and fungi in the rhizosphere showed no significant correlation to soil enzyme activity. Conversely, the composition of bacteria in non-rhizosphere soil was significantly positively correlated to catalase, sucrase, and phosphatase. Fungal diversity in non-rhizosphere soil was also positively correlated to sucrose (Table 5). The reason for this could be that microorganisms in non-rhizosphere soil are more involved in the process of enzyme synthesis compared to the rhizosphere and rhizosphere microbes are mainly affected by secondary metabolites, such as root secretions.

Table 5. Relationships of microbial compositions and diversities to different soil enzyme activities by a Mantel test.

\begin{tabular}{lccccccccc}
\hline & & \multicolumn{2}{c}{ Catalase } & \multicolumn{2}{c}{ Urease } & \multicolumn{2}{c}{ Sucrase } & \multicolumn{2}{c}{ Phosphatase } \\
\cline { 3 - 9 } & & $\mathbf{r M}$ & $p$ & $\mathbf{r M}$ & $p$ & $\mathbf{r M}$ & $p$ & rM & $p$ \\
\hline \multirow{4}{*}{ Rhizosphere } & Bacterial composition & 0.1413 & 0.096 & 0.15340 & 0.053 & 0.09360 & 0.105 & 0.11460 & 0.172 \\
& Fungal composition & -0.1320 & 0.914 & -0.04207 & 0.652 & 0.02596 & 0.357 & -0.02459 & 0.564 \\
& Bacterial diversity & -0.1435 & 0.907 & -0.07609 & 0.739 & 0.1285 & 0.056 & -0.15320 & 0.934 \\
& Fungal diversity & -0.1065 & 0.851 & -0.1058 & 0.863 & 0.03853 & 0.217 & -0.05151 & 0.658 \\
\hline \multirow{5}{*}{ Non-rhizosphere } & Bacterial composition & 0.2178 & $\mathbf{0 . 0 2 4}$ & 0.16830 & 0.064 & 0.1573 & $\mathbf{0 . 0 2 6}$ & 0.27940 & $\mathbf{0 . 0 0 8}$ \\
& Fungal composition & -0.1320 & 0.932 & -0.04207 & 0.675 & 0.02596 & 0.343 & -0.02459 & 0.620 \\
& Bacterial diversity & -0.06443 & 0.664 & 0.01617 & 0.412 & 0.1481 & 0.065 & 0.001121 & 0.415 \\
& Fungal diversity & -0.09926 & 0.731 & 0.07597 & 0.236 & 0.2057 & $\mathbf{0 . 0 2 4}$ & -0.02155 & 0.428 \\
\hline
\end{tabular}

Note: Significant $p$-values are in bold print.

\subsection{Driving Factors of Microbial Composition and Diversity in Rhizosphere and Non-Rhizosphere Soil}

According to results from the Mantel test, restoration time played the most significant role in the composition of bacteria and fungi and in bacterial diversity, but restoration time had no effect on fungal diversity in rhizosphere and non-rhizosphere soil (Table 6). 
Table 6. Relationships of microbial compositions and diversities to soil and root variables, restoration years and transfer factors by Mantel test.

\begin{tabular}{|c|c|c|c|c|c|c|c|c|c|c|c|c|c|}
\hline & & \multicolumn{2}{|c|}{ Soil Enzyme Activity } & \multicolumn{2}{|c|}{ Soil Heavy Metals } & \multicolumn{2}{|c|}{ Root Properties } & \multicolumn{2}{|c|}{ Root Heavy Metals } & \multicolumn{2}{|c|}{ Restoration Years } & \multicolumn{2}{|c|}{ Transfer Factors } \\
\hline & & $r M$ & $p$ & $r M$ & $p$ & $r M$ & $p$ & $r M$ & $p$ & $r M$ & $p$ & $r M$ & $p$ \\
\hline \multirow{4}{*}{ Rhizosphere } & Bacterial composition & -0.03053 & 0.619 & -0.14950 & 0.941 & -0.0348 & 0.647 & 0.00050 & 0.498 & 0.3124 & 0.001 & 0.1149 & 0.127 \\
\hline & Fungal composition & -0.00690 & 0.548 & 0.10840 & 0.101 & -0.0487 & 0.717 & -0.02232 & 0.592 & 0.3052 & 0.001 & -0.1714 & 0.985 \\
\hline & Bacterial diversity & -0.05227 & 0.720 & 0.07106 & 0.198 & -0.2032 & 0.990 & -0.04485 & 0.690 & 0.3417 & 0.001 & -0.1207 & 0.893 \\
\hline & Fungal diversity & -0.03539 & 0.652 & -0.05688 & 0.764 & 0.02572 & 0.362 & -0.08115 & 0.807 & 0.01618 & 0.354 & 0.05851 & 0.262 \\
\hline \multirow{4}{*}{ Non-rhizosphere } & Bacterial composition & 0.02491 & 0.408 & 0.00248 & 0.504 & 0.1211 & 0.114 & 0.07338 & 0.200 & 0.4749 & 0.001 & 0.1037 & 0.169 \\
\hline & Fungal composition & -0.00690 & 0.516 & 0.10840 & 0.093 & -0.0487 & 0.714 & -0.02232 & 0.584 & 0.3052 & 0.001 & -0.1714 & 0.985 \\
\hline & Bacterial diversity & -0.04229 & 0.610 & 0.01901 & 0.438 & -0.1590 & 0.939 & -0.05650 & 0.659 & 0.3812 & 0.001 & -0.0217 & 0.532 \\
\hline & Fungal diversity & 0.02797 & 0.360 & -0.1138 & 0.806 & -0.1367 & 0.878 & -0.09095 & 0.719 & 0.1195 & 0.063 & -0.0440 & 0.542 \\
\hline
\end{tabular}

Note: Significant $p$-values are in bold print. 
The results from bacterial evenness from the Margalef's richness index $(d M a)$ and bacterial richness from the species richness test $(S)$ in the $S 525$ sub-dam were significantly higher than in the other sub-dams in rhizosphere and non-rhizosphere soil and results from the evenness index (En) in the S536 sub-dam were significantly higher than in the other sub-dams (Figure 4A,C). Findings on rhizosphere bacterial diversity from the Shannon-Wiener index $\left(H^{\prime}\right)$ and the Simpson's Diversity Index $(D)$ in the S536 and S525 sub-dams were significantly higher than in the S523 and S529 sub-dams (Figure 4A). In addition, findings from the Shannon-Wiener index and the Simpson's Diversity Index on non-rhizosphere soil bacteria in the S525 sub-dam were higher than in the S523, S531, and S536 sub-dams (Figure 4C).
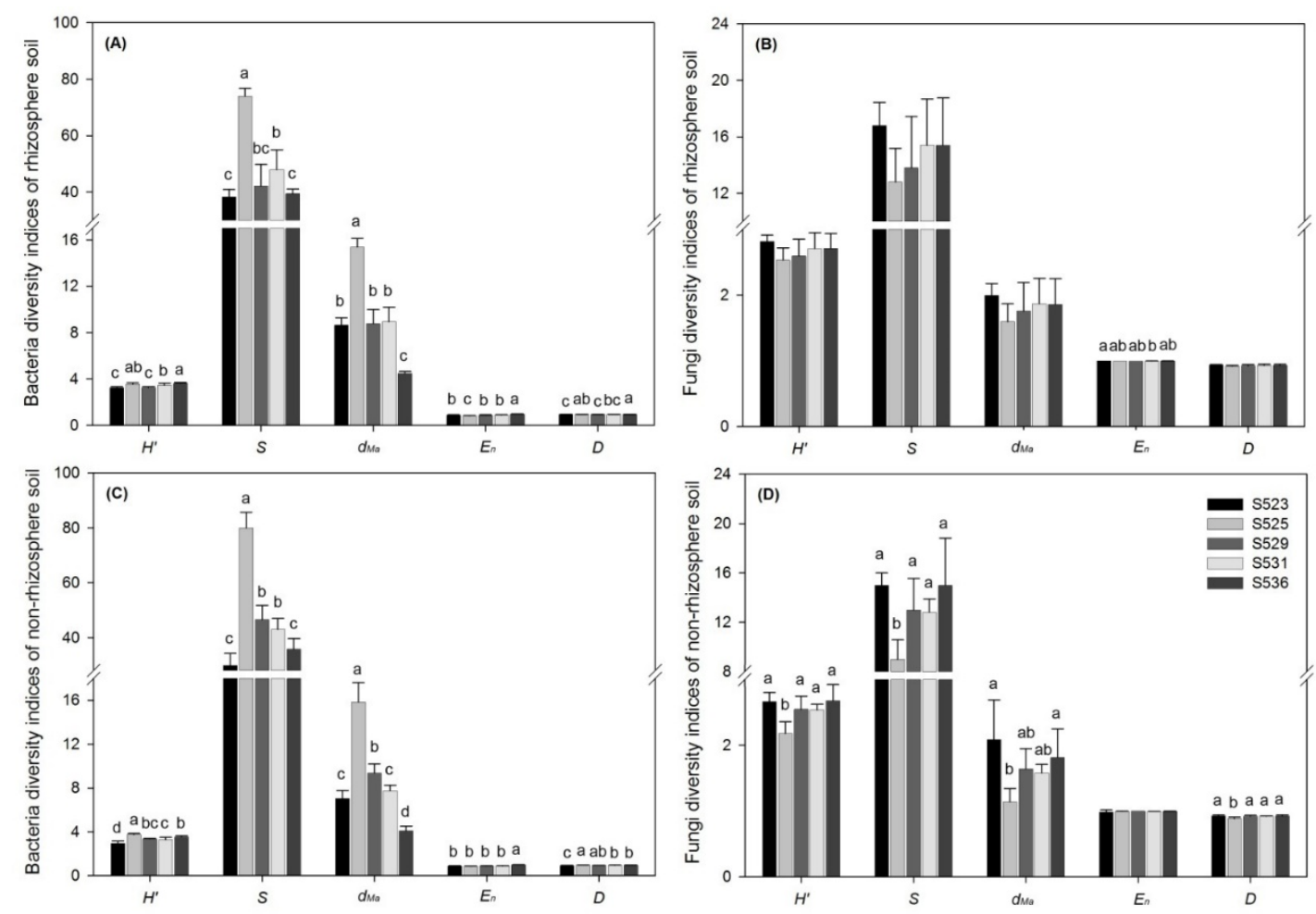

Figure 4. Shannon-Wiener index $\left(H^{\prime}\right)$, Species richness $(S)$, Margalef $\left(d_{M a}\right)$, Evenness $\left(E_{n}\right)$, and Simpson index $(D)$ of rhizosphere $(\mathbf{A}, \mathbf{B})$ and non-rhizosphere $(\mathbf{C}, \mathbf{D})$ soil bacteria $(\mathbf{A}, \mathbf{C})$ and fungi $(\mathbf{B}, \mathbf{D})$ community in different sub-dams. Different letters $(a, b$ and $c)$ indicate significant differences, according to Duncan's test $(p<0.05)$.

The results from the evenness index in the S523 sub-dam were significantly higher than in the S531 sub-dam for fungi (Figure 4B). Conversely, diversity significantly differed among the different restoration times with the exception of results from the evenness index on fungi in non-rhizosphere soil. At the same time, results from the Shannon-Wiener index, species richness, and the Simpson's Diversity Index on non-rhizosphere fungi in the S525 sub-dam were significantly lower than in the other sub-dams (Figure 4D), which was opposite to the results observed for non-rhizosphere bacteria. This may be due to the different survival strategies of bacteria and fungi in soil.

According to results from the Mantel test, rhizosphere bacteria composition was significantly correlated to the $\mathrm{Zn}$ transfer factor $(\mathrm{r}=0.2294, p=0.008)$ and $\mathrm{Pb}$ content in roots $(\mathrm{r}=0.1653, p=0.019)$. Bacterial diversity was significantly correlated to soil C $(r=0.2345, p=0.008)$, but the composition and diversity of non-rhizosphere bacteria did not correlate to the other factors.

Fungal composition was significantly correlated to soil C (rhizosphere: $r=0.2037, p=0.015$, non-rhizosphere: $\mathrm{r}=0.2037, p=0.02$ ) and $\mathrm{pH}$ (rhizosphere: $\mathrm{r}=0.2152, p=0.002$, non-rhizosphere: $\mathrm{r}=0.2152, p=0.002)$. Rhizosphere fungal diversity was significantly correlated to $\mathrm{NO}_{3}{ }^{-}-\mathrm{N}(\mathrm{r}=0.1613$, $p=0.035)$ and non-rhizosphere fungal diversity was significantly correlated to PS $(\mathrm{r}=0.3897, p=0.011)$. 
3.6. Correlation between Soil Properties and Microbial Diversity of Rhizosphere and Non-Rhizosphere Soil for the Different Restoration Times

The driving factors of microbial composition and diversity varied in rhizosphere and non-rhizosphere soil among the different restoration times (Figure 5). Results from the species richness test and the Margalef's richness index on bacteria in the rhizosphere were significantly and positively correlated to $\mathrm{NO}_{3}{ }^{-}-\mathrm{N}$ and the evenness index was negatively correlated to PS and $\mathrm{Zn}$. Fungal diversity in non-rhizosphere soil was significantly correlated to PS in the S523 sub-dam (Figure 5). Results from the species richness test and the Margalef's richness index on bacteria in the rhizosphere were significantly and negatively correlated to N in the S525 sub-dam. The results from the Shannon-Wiener index and the evenness index on bacteria in the rhizosphere were negatively correlated to $C$ and fungal diversity in non-rhizosphere soil was negatively correlated to $\mathrm{NH}_{4}{ }^{+}-\mathrm{N}$ (Figure 5).

Furthermore, fungal diversity in the rhizosphere was negatively correlated to soil $\mathrm{Cu}$ and negatively correlated to PS in non-rhizosphere soil of the S529 sub-dam (Figure 5). Results from the species richness test and the Margalef's richness index on bacteria in the rhizosphere were significantly positively correlated to $\mathrm{NH}_{4}{ }^{+}-\mathrm{N}$ and negatively correlated to $\mathrm{Pb}$ in the $\mathrm{S} 531$ sub-dam (Figure 5). Additionally, fungal diversity in the rhizosphere was significantly correlated to the $\mathrm{C} / \mathrm{N}$ ratio and the soil fungi in the non-rhizosphere was significantly correlated to $\mathrm{NO}_{3}{ }^{-}-\mathrm{N}$, total $\mathrm{N}$, the $\mathrm{C} / \mathrm{N}$ ratio and Zn (Figure 5). 


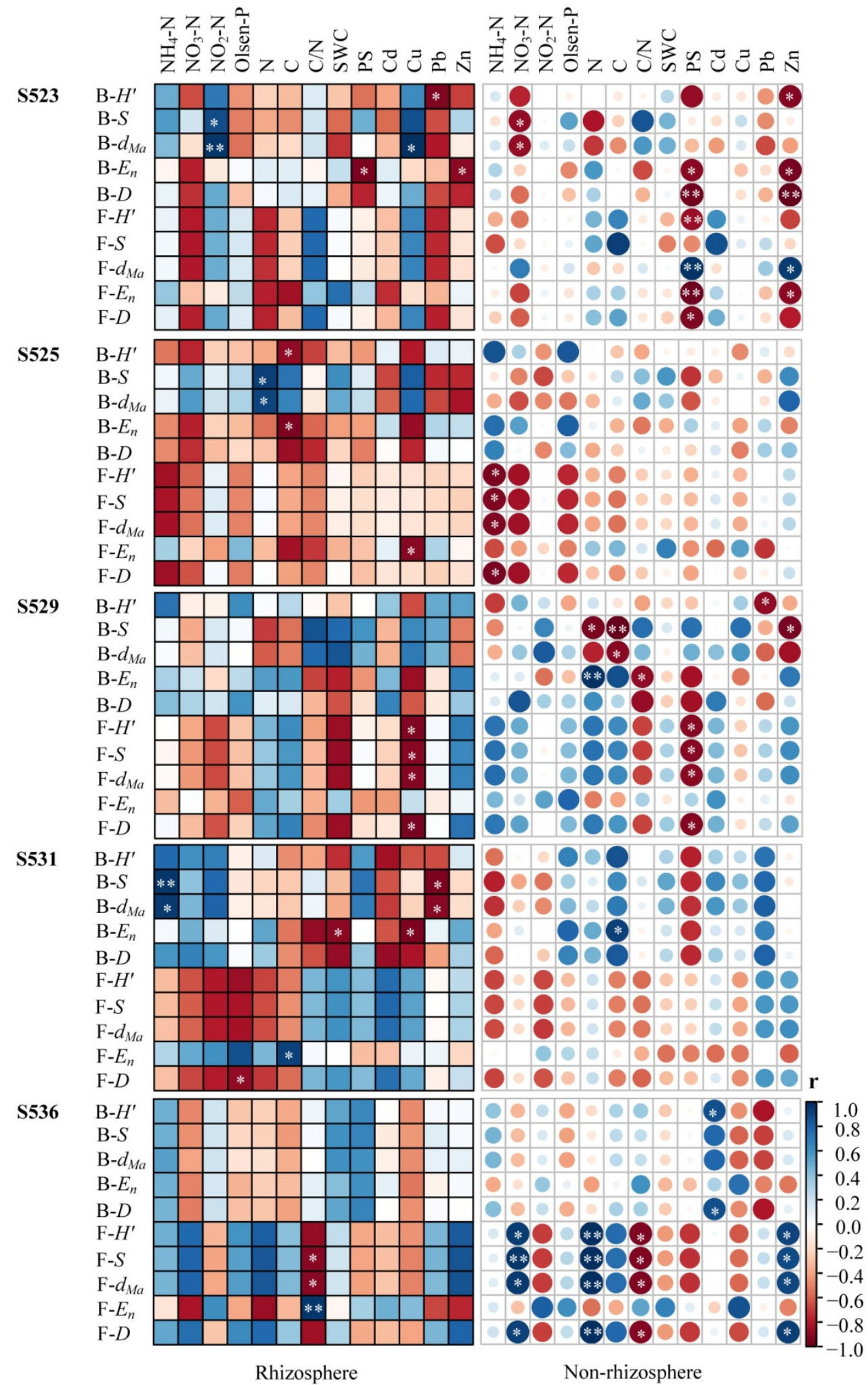

Figure 5. The Pearson correlations between soil properties and Shannon-Wiener index $\left(H^{\prime}\right)$, species richness $(S)$, Margalef $\left(d_{M a}\right)$, evenness $\left(E_{n}\right)$ and the Simpson index $(D)$ of rhizosphere and non-rhizosphere soil bacteria (B) and fungi (F) community in different sub-dams. Soil properties include total nitrogen $(\mathrm{N})$, total carbon $(\mathrm{C})$, total sulphur $(\mathrm{S})$, and a ratio of carbon and nitrogen $(\mathrm{C} / \mathrm{N})$. ** Correlation is significant at the 0.01 level (2-tailed). ${ }^{*}$ Correlation is significant at the 0.05 level (2-tailed). 


\section{Discussion}

\subsection{Soil Enzyme Activity and Driving Factors}

Soil enzymes are one of the most active soil organic ecosystem components and they are involved in all biochemical processes within the soil environment. Additionally, soil enzymes are not only the agent for which soil organic transformations take place. They are also an active pool of plant nutrients [29]. Soil enzyme activity is also widely used as a biological index to evaluate soil health.

The results from this study showed that heavy metal pollution in soil could affect the function of soil biology, the diversity of the microbial community [30], and the transformation of C, N, P, and $S$ in soil [31]. This study found significant differences in soil nutrients and enzyme activities [32]. This finding is in agreement with a previous study that showed that there were significant differences in soil physicochemical properties over different reclamation years [25]. Catalase activity indicates the degree of soil humus and organic matter accumulation and its relevance to organic matter content. Catalase is often used as a soil fertility indicator [33].

Urease can catalyze and hydrolyze urea into ammonia or ammonia ions. Additionally, among enzymes, urease has the most significant effect on the soil $\mathrm{N}$ cycle [34]. The results from our study consistently showed that soil $\mathrm{N}$ was highly and significantly positively correlated to catalase and urease (Table 3). Mantel test results showed that there was a significant correlation between enzyme activity and $\mathrm{Zn}$ in soil $(\mathrm{r}=0.4012, p=0.017)$. A possible explanation for this is that the soil substrate, or soil substrates, where soil protein chelation has taken place, become more complex in the presence of heavy metals or they react with enzyme substrates and produce complex reactions that inhibit soil enzyme activities [35]. Among the soil enzyme types, dehydrogenase, urease, and phosphatase are particularly important for nutrient transformation to take place in plants [36,37]. Furthermore, plant roots also directly affect soil enzyme activities [38]. Our study found that As content decreased gradually, total $\mathrm{C}$ and $\mathrm{N}$ in the stems of $B$. ischaemum increased with an increase in restoration time. There was a significant negative correlation between phosphatase activity and total $C$ and $S$ in the roots of B. ischaemum (Table 3). The effect of plant nutrients on enzyme activities could potentially be explained by two factors: (1) through substrate induction likely caused by the aboveground vegetation litter input, which appears to influence soil enzyme activities [39] and (2) through varied plant root stimulation on enzyme activities resulting from their different effects on microbial activity and exudate richness production in substrates [40].

Furthermore, this study also verified that bacterial composition was positively correlated to catalase, sucrase, and phosphatase and fungal diversity was also positively correlated to sucrase in non-rhizosphere soil. Nevertheless, there was no correlation between bacterial and fungal composition and diversity and soil enzyme activity in the rhizosphere (Table 5). To explain such findings, it could be reasoned that soil enzymes acted catalytically with bioactive substances secreted by microorganisms, animals, and plants and they were then released through animal and plant residue that decomposed in the soil [41]. Soil enzymes mainly derived from microorganisms in non-rhizosphere soil, which include intracellular enzymes existing in living cells and extracellular enzymes that exist in soil solutions or are adsorbed on the surface of soil particles [42,43]. Hence, microorganisms in non-rhizosphere soil have significantly greater effects on soil enzyme activity when compared to rhizosphere soil.

\subsection{Microbial Gene Abundance and Diversity in Rhizosphere and Non-Rhizosphere Soil}

Environmental factors and soil conditions such as soil moisture, directly influence microbial community structure and activity [44]. Furthermore, our study indicated that restoration time had a significant effect on diversity and gene abundance of both bacteria and fungi while specific micro-ecosystems in the rhizosphere mainly affected fungal diversity (Table 4). In addition, the number of bacterial gene copies in rhizosphere soil and fungi in non-rhizosphere soil was significantly different among the sub-dams investigated in this study (Figure 2). This was consistent with findings by $\mathrm{Li}$ et al. showed that reclamation scenarios determined soil microbial abundance, diversity, 
and composition [32]. Moreover, microbes in the rhizosphere of the different sub-dams could differ significantly. Therefore, the restoration time of different sub-dams and the specific micro-ecosystem in the rhizosphere could also have an effect on microbial community composition and diversity.

Micro-ecosystems in the rhizosphere, being the most active part of the global biochemical cycle, are the bond that bind plants, soil, and microbes and it is the core region of biogeochemical cycling that organically connects the atmosphere, biosphere, and pedosphere $[45,46]$. Our study revealed that the number of rhizosphere bacterial gene copies in the S525 and S529 sub-dams was higher than the other three sub-dams investigated and the number of non-rhizosphere fungal gene copies in the S525 and S529 sub-dams was higher than the other sub-dams investigated (Figure 2). A probable reason for this was that bacteria play a crucial role in ecological stability during the initial restoration phase [47] and a previous study reported that forest succession promoted a dominated soil fungal community [48]. In a pampa biome, the fungal community structure was more affected by land-use type [49]. These findings suggested that soil bacteria and fungi play different ecological roles [32].

Bacterial diversity results from the species richness and Margalef's richness indices in rhizosphere and non-rhizosphere soil of the S525 sub-dam were significantly higher than the other sub-dams while bacterial diversity results from the Shannon-Wiener and Simpson indices in non-rhizosphere soil of the S525 sub-dam were higher than the S523, S531, and S536 sub-dams (Figure 4C). However, the opposite was true for fungi in non-rhizosphere soil. Fungal diversity results from the Shannon-Wiener, species richness, and Simpson indices in non-rhizosphere soil of the S525 sub-dam were significantly lower than in the other sub-dams (Figure 4D). A potential reason for this is that bacteria and fungi possess different survival strategies in soil. Furthermore, the ratios of fungal to bacterial (F/B) biomass also correlated to restoration processes due to the fact that elevated ratios could indicate the amount and composition of litter that enters the soil given that fungi are the dominant decomposers of plant cell wall polymers in the litter [50]. There were significant differences in F/B ratios in the rhizosphere under different restoration times and the F/B ratio in the S531 sub-dam was significantly higher than in the rhizosphere of the S525 and S529 sub-dams. Moreover, F/B ratios of microbes in non-rhizosphere soil showed that the S525 sub-dam was significantly higher than the S523, S529, and S531 sub-dams (Figure 3). We found that the S531 and S525 sub-dams had the highest F/B ratios in rhizosphere and non-rhizosphere soil, respectively (Figure 3), which could be indicative of a significant increase in fungal abundance under greater plant diversity [51].

\subsection{Driving Factors of Soil Microbial Community Composition and Structure in Rhizosphere and Non-Rhizosphere Soil under Different Restoration Times}

The composition of the soil microbial community is influenced by many environmental factors. Soil properties strongly influence microbial composition and microbial functionality within the soil system [52] such as soil moisture [53], agrotype [54], soil physicochemical properties [55], vegetation type and diversity [56], heavy metal type and content [57], and restoration time [58]. The species evenness of bacteria in the rhizosphere of the S523 sub-dam was negatively correlated to PS; fungal diversity in non-rhizosphere soil was significantly correlated to PS. Fungal diversity in non-rhizosphere soil of the S529 sub-dam was mainly negatively correlated to PS (Figure 5). These results implied that these microbial communities were closely correlated to soil physicochemical properties. Previous studies have also supported the hypothesis that states PS has a significant effect on microbial community structure [24].

In this study, sub-dam soil was alkaline ( $\mathrm{pH}=7.88-8.11)$. Mantel test results demonstrated that rhizosphere bacteria were significantly correlated to the $\mathrm{Zn}$ transfer factor $(\mathrm{r}=0.2294, p=0.008)$ and $\mathrm{Pb}$ content in roots $(r=0.1653, p=0.019)$. Additionally, rhizosphere fungal diversity in the S529 sub-dam had a significant negative correlation to $\mathrm{Cu}$ in soil (Figure 5). This indicated that the soil microbial community of the different sub-dams was influenced by different driving factors even though both soil types (i.e., rhizosphere and non-rhizosphere soil) shared a similar $\mathrm{pH}$ profile $(\mathrm{pH}=$ alkaline) [59]. 
On the other hand, the nature of the contaminant (e.g., heavy metal pollution) could affect microbial diversity and abundance [60].

Soil $\mathrm{pH}$ is one of the most important and basic soil properties and acts as an index of soil formation and fertilizer cultivation, which have a significant influence on the form and availability of soil nutrients, soil physical properties, chemical properties, microbial activity and plant growth and development [61]. We found that there was a significant correlation between rhizosphere bacterial diversity and soil $C(\mathrm{r}=0.2345, p=0.008)$, and fungal composition in rhizosphere and non-rhizosphere soil was significantly correlated to soil $\mathrm{C}$ and $\mathrm{pH}$. It is widely believed among the scientific community that soil $\mathrm{C}$ and soil $\mathrm{pH}$ have a direct influence on soil microbial communities [62]. Our findings supported the hypothesis that rhizosphere and non-rhizosphere soil communities from different sub-dams would differ and results from our study support results from other studies [59,63].

Microbes, being the driving factor of biogeochemical cycling, are a crucial ecosystem component. Total $\mathrm{C}$ and $\mathrm{N}$ content in soil is the key factor that affects microbial biomass and activity [64]. In this study, results from the species richness and Margalef's richness indices demonstrated that bacteria in the rhizosphere was positively correlated to $\mathrm{N}$ content while results from the Shannon-Wiener and evenness indices demonstrated that bacteria in the rhizosphere was significantly and negatively correlated to C content in the S525 sub-dam (Figure 5). In soil, C and N provide energy to microbes and aid in the formation of cell components to maintain microbial subsistence. Furthermore, the soil $\mathrm{C} / \mathrm{N}$ ratio reflects the biological activities of soil bacterial communities and quantifies mineralization and sequestration characteristics of $\mathrm{C}$ and $\mathrm{N}$ in soil, which is an important indicator of soil $\mathrm{C}$ and $\mathrm{N}$ cycling [65,66]. Generally, the $\mathrm{C} / \mathrm{N}$ ratio is inversely proportional to its decomposition rate [67]. Bacteria are required to input $\mathrm{N}$ to satisfy their growth needs when the $\mathrm{C} / \mathrm{N}$ ratio is high. However, under lower $\mathrm{C} / \mathrm{N}$ ratios, redundant $\mathrm{N}$ from bacterial growth is released into litter and soil [68].

The results from the species richness and Margalef's richness indices in this study demonstrated that the rhizosphere bacterial community was positively correlated to $\mathrm{NO}_{3}{ }^{-}-\mathrm{N}$ and that fungal diversity in non-rhizosphere soil in the S525 sub-dam was to a great extent negatively correlated to $\mathrm{NH}_{4}{ }^{+}-\mathrm{N}$. Moreover, results from the species richness and Margalef's richness indices found that the rhizosphere bacterial community in the S531 sub-dam was significantly and positively correlated to $\mathrm{NH}_{4}{ }^{+}-\mathrm{N}$ in soil and that fungal diversity in the rhizosphere of the $\mathrm{S} 536$ sub-dam was significantly correlated to the $\mathrm{C} / \mathrm{N}$ ratio. Additionally, the fungal community in non-rhizosphere soil was significantly correlated to $\mathrm{NO}_{3}{ }^{-}-\mathrm{N}$, total N, C/N, and $\mathrm{Zn}$ (Figure 5), which indicated that the driving factors of microbial composition and diversity in rhizosphere and non-rhizosphere soil varied during restoration times investigated. On the one hand, this may be due to the mineralization and decomposition of soil organic matter and that nutrient transformation differed during the different restoration times $[69,70]$. In addition, the different $C$ sources could result from how vegetation restoration patterns significantly influence metabolic activities and functional diversity of microbial communities in sandy soil [62]. On the other hand, vegetation production varied in the different sub-dams under different restoration times. Most microorganisms are heterotrophs that require nutrients provided by plants. Soil microorganisms will also decompose organic matter and litter in the case of nutrient available for plant growth [71]. Root exudates could also influence microbial communities in rhizosphere and non-rhizosphere soil [72,73]. These factors indicated that the significant effects that vegetation has on soil microbial communities could be due to differences in litter inputs and root exudates [74,75]. Findings from this study could be used to explore microbial structures and their influencing factors for the ecological restoration of mining areas and also provide a scientific basis to further understand the functional potential of microorganisms.

\section{Conclusions}

In this study, we found that arsenic content decreased gradually as restoration time increased. Total $\mathrm{C}$ in shoots and total $\mathrm{N}$ in roots of $B$. ischaemum also increased as restoration time increased. In addition, total $\mathrm{N}$ in soil was highly and remarkably positively correlated to catalase and urease 
but highly and significantly negatively correlated to sucrose. Bacterial composition was positively correlated to catalase, sucrase, and phosphatase, and fungal diversity was positively correlated to sucrose in bulk soil. Moreover, restoration time was the main impact factor for bacterial and fungal composition and bacterial diversity and the driving factors of microbial composition and diversity varied in rhizosphere and non-rhizosphere soil for the different restoration times investigated.

Author Contributions: Conceived and designed the experiments: T.J. Performed the experiments: M.C. and R.W. Analyzed the data: T.J. Wrote the paper: T.J.

Funding: The research was supported by the National Natural Science Foundation of China (grant no. 31600308), the Shanxi Province Science Foundation for Youths (grant no. 201601D021101), and the Shanxi Province Foundation for Returness (grant no. 2016-006).

Conflicts of Interest: The funders had no role in the design of the study, in the collection, analyses, or interpretation of data, in the writing of the manuscript, or in the decision to publish the results.

\section{References}

1. Luilo, G.B.; Othman, O.C.; Mrutu, A. Arsenic: A toxic trace element of public health concern in urban roadside soils in Dar es Salaam City. J. Mater. Environ. Sci. 2014, 5, 1742-1749.

2. Kelley, S.L.; Aitchison, E.W.; Deshpande, M.; Schnoor, J.L.; Alvarez, P.J. Biodegradation of 1,4-dioxane in planted and unplanted soil: Effect of bioaugmentation with Amycolata sp. CB1190. Water Res. 2001, 35, 3791-3800. [CrossRef]

3. Bankston, J.L.; Sola, D.L.; Komor, A.T.; Dwyer, D.F. Degradation of trichloroethylene in wetland microcosms containing broad-leaved cattail and eastern cottonwood. Water Res. 2002, 36, 1539-1546. [CrossRef]

4. Siciliano, S.D. Plant-bacterial combinations to phytoremediate soil contaminated with high concentrations of 2,4,6-trinitrotoluene. J. Environ. Qual. 2000, 29, 311-316. [CrossRef]

5. Yateem, A.; Balba, M.T.; Elnawawy, A.S.; Alawadhi, N. Plants-associated microflora and the remediation of oil-contaminated soil. Int. J. Phytoremediat 2000, 2, 183-191. [CrossRef]

6. Mehmannavaz, R.; Prasher, S.O.; Ahmad, D. Rhizospheric effects of alfalfa on biotransformation of polychlorinated biphenyls in a contaminated soil augmented with Sinorhizobium Meliloti. Process. Biochem. 2002, 37, 955-963. [CrossRef]

7. Caldwell, B.A. Enzyme activities as a component of soil biodiversity: A review. Pedobiol. Int. J. Soil Boil. 2005, 49, 637-644. [CrossRef]

8. Angle, J.S.; Baker, A.J.M.; Whiting, S.N.; Chaney, R.L. Soil moisture effects on uptake of metals by Thlaspi, Alyssum, and Berkheya. Plant Soil 2003, 256, 325-332. [CrossRef]

9. Tabatabai, M.A.; Dick, W.A.; Burns, R.G.; Dick, R.P. Enzymesin Soil: Research and Developments in Measuring Activities; Marcel Dekker, Inc.: New York, NY, USA, 2002; pp. 567-596.

10. Feng, J.; Zheng, X.; Yang, Z.; Chen, S.; Chen, H. Effects of five kinds of cultivation on the soil microorganisms and enzyme activities of camellia oleifera forestry. J. Southwest For. Univ. 2016, 36, 10-16.

11. Guo, X.; Gu, J.; Chen, Z.; Gao, H.; Qin, Q.; Sun, W.; Zhang, W. Effects of heavy metals pollution on soil microbial communities metabolism and soil enzyme activities in coal mining area of Tongchuan, Shaanxi Province of Northwest China. Chin. J. Appl. Ecol. 2012, 23, 798-806.

12. Hou, Y.; Zhou, H.; Zhang, C. Effects of urbanization on community structure of soil microorganism. Ecol. Environ. Sci. 2014, 7, 1108-1112.

13. Li, W.; Wei, J.; Liu, A.; Wang, Y.; Zhu, Z.; Wang, X. Effects of chlorophytum comosum growth on microbial biomass and soil enzymatic activities in zinc-polluted soil. J. Soil Water Conserv. 2013, 27, $276-281$.

14. Gao, Y.; Mao, L.; Zhou, P.; Zhi, Y.; Zhang, C. Effect of plant growth on soil enzyme activity and microbe community structure under $\mathrm{Cd}$ and Pb stress. Acta Sci. Nat. Univ. Pekin. 2010, 46, 339-345.

15. Wiehe, W.; Höflich, G. Survival of plant growth promoting rhizosphere bacteria in the rhizosphere of different crops and migration to non-inoculated plants under field conditions in north-east Germany. Microbiol. Res. 1995, 150, 201-206. [CrossRef]

16. Mendes, R.; Kruijt, M.; De, B.I.; Dekkers, E.; Van, D.V.M.; Schneider, J.H.; Piceno, Y.M.; Desantis, T.Z.; Andersen, G.L.; Bakker, P.A. Deciphering the rhizosphere microbiome for disease-suppressive bacteria. Science 2011, 332, 1097-1100. [CrossRef] [PubMed] 
17. Mendes, R.; Garbeva, P.; Raaijmakers, J.M. The rhizosphere microbiome: Significance of plant beneficial, plant pathogenic, and human pathogenic microorganisms. FEMS Microbiol. Rev. 2013, 37, 634-663. [CrossRef] [PubMed]

18. Elgersma, K.J.; Shen, Y.; Vor, T.; Ehrenfeld, J.G. Microbial-mediated feedbacks of leaf litter on invasive plant growth and interspecific competition. Plant Soil 2012, 356, 341-355. [CrossRef]

19. Paterson, E.; Gebbing, T.; Abel, C.; Sim, A.; Telfer, G. Rhizodeposition shapes rhizosphere microbial community structure in organic soil. New Phytol. 2007, 173, 600-610. [CrossRef] [PubMed]

20. Li, J.; Liu, F.; Zhou, X. Effects of Different Reclaimed Scenarios on Soil Microbe and Enzyme Activities in Mining Areas. Environ. Sci. 2015, 36, 1836-1841.

21. Ciarkowska, K.; Sołekpodwika, K.; Wieczorek, J. Enzyme activity as an indicator of soil-rehabilitation processes at a zinc and lead ore mining and processing area. J. Environ. Manag. 2014, 132, 250-256. [CrossRef] [PubMed]

22. Schimann, H.; Petit-Jean, C.; Guitet, S.; Reis, T.; Domenach, A.M.; Roggy, J. Microbial bioindicators of soil functioning after disturbance: The case of gold mining in tropical rainforests of French Guiana. Ecol. Indic 2012, 20, 34-41. [CrossRef]

23. Li, H.; Shao, H.; Li, W.; Bi, R.; Bai, Z. Improving soil enzyme activities and related quality properties of reclaimed soil by applying weathered coal in opencast-mining areas of the Chinese Loess Plateau. Clean Soil Air Water 2012, 40, 233-238. [CrossRef]

24. Tong, J.; Miaowen, C.; Juhui, J.; Jinxian, L.; Baofeng, C. Endophytic fungi and soil microbial community characteristics over different years of phytoremediation in a copper tailings dam of Shanxi, China. Sci. Total Environ. 2017, 574, 881-888. [CrossRef] [PubMed]

25. Wang, R.; Jia, T.; Cao, M.; Chai, B. Characteristics of Soil Physicochemical Properties and Enzyme Activities over Different Characteristics of soil physicochemical properties and enzyme activities over different reclaimed years in a copper tailings dam. Environ. Sci. 2018, 39, 3339-3348.

26. Liu, J.; Li, C.; Jing, J.; Zhao, P.; Luo, Z.; Cao, M.; Ma, Z.; Jia, T.; Chai, B. Ecological patterns and adaptability of bacterial communities in alkaline copper mine drainage. Water Res. 2018, 133, 99-109. [CrossRef] [PubMed]

27. Qiao, S.; Zhou, Y.; Liu, J.; Jing, J.; Jia, T.; Li, C.; Yang, X.; Chai, B. Characteristics of Soil Bacterial Community Structure in Coniferous Forests of Guandi Mountains, Shanxi Province. Sci. Silvae Sin. 2017, 53, 89-99.

28. Yang, Y.; Song, Y.; Scheller, H.V.; Ghosh, A.; Ban, Y.; Chen, H.; Tang, M. Community structure of arbuscular mycorrhizal fungi associated with Robinia pseudoacacia in uncontaminated and heavy metal contaminated soils. Soil Boil. Biochem. 2015, 86, 146-158. [CrossRef]

29. Badiane, N.N.Y.; Chotte, J.L.; Pate, E.; Masse, D.; Rouland, C. Use of soil enzyme activities to monitor soil quality in natural and improved fallows in semi-arid tropical regions. Appl. Soil Ecol. 2001, 18, 229-238. [CrossRef]

30. Chander, K.; Dyckmans, J.; Joergensen, R.; Meyer, B.; Raubuch, M. Different sources of heavy metals and their long-term effects on soil microbial properties. Biol. Fert. Soils 2001, 34, 241-247. [CrossRef]

31. Belyaeva, O.N.; Haynes, R.J.; Birukova, O.A. Barley yield and soil microbial and enzyme activities as affected by contamination of two soils with lead, zinc or copper. Biol. Fert. Soils 2005, 41, 85-94. [CrossRef]

32. Li, J.; Zhou, X.; Yan, J.; Li, H.; He, J. Effects of regenerating vegetation on soil enzyme activity and microbial structure in reclaimed soils on a surface coal mine site. Appl. Soil Ecol. 2015, 87, 56-62. [CrossRef]

33. Ji, Y.; Feng, W.; Chen, L.; Duan, W.; Zhang, X. Soil nutrition, microorganisms and enzyme activity of the rhizosphere and non-rhizosphere soils of mixed plantation of Larix. Ecol. Environ. 2008, 17, 339-343.

34. Dick, R.P.; Pankhurst, C.; Doube, B.M.; Gupta, V.V.S.R. Soil Enzyme Activitiesas Integrative Indicators of Soil Health; FAO: Rome, Italy, 1997; pp. 121-156.

35. Moreno, J.L.; García, C.; Hernández, T. Toxic effect of cadmium and nickel on soil enzymes and the influence of adding sewage sludge. Eur. J. Soil Sci. 2003, 54, 377-386. [CrossRef]

36. Duan, X.; Min, H. Effects of $\mathrm{Cd}^{2+}$ on the biological activities and the enzyme activities in submerged paddy soil. J. Agro-Environ. Sci. 2004, 23, 422-427.

37. Huang, Z.; Min, H.; Lu, Z.; Jin, W.; Yuan, H. Study on the effects of mono-contamination of $\mathrm{Cu}^{2+}$ and associated-contamination of $\mathrm{Cu}^{2+}$ and $\mathrm{Cd}^{2+}$ on enzyme activities in flooded paddy soil. J. Zhejiang Univ. (Agric. Life Sci.) 2006, 32, 557-562.

38. Pant, H.K.; Warman, P.R. Enzymatic hydrolysis of soil organic phosphorus by immobilized phosphatases. Biol. Fert. Soils 2000, 30, 306-311. [CrossRef] 
39. Tischer, A.; Blagodatskaya, E.; Hamer, U. Extracellular enzyme activities in a tropical mountain rainforest region of southern Ecuador affected by low soil P status and land-use change. Appl. Soil Ecol. 2014, 74, 1-11. [CrossRef]

40. Salam, A.K.; Katayama, A.; Kimura, M. Activities of some soil enzymes in different land use systems after deforestation in hilly areas of West Lampung, South Sumatra, Indonesia. Soil Sci. Plant Nutr. 1998, 44, 93-103. [CrossRef]

41. Calbrixa, R.; Barray, S. Analysis of the potential functional diversity of the bacterial community in soil: A reproducible procedure using sole-carbon-source utilization profiles. Eur. J. Soil Biol. 2005, 41, 11-20. [CrossRef]

42. Burns, R.G.; Deforest, J.L.; Marxsen, J.; Sinsabaugh, R.L.; Stromberger, M.E.; Wallenstein, M.D.; Weintraub, M.N.; Zoppini, A. Soil enzymes in a changing environment: Current knowledge and future directions. Soil Biol. Biochem. 2013, 58, 216-234. [CrossRef]

43. Zornoza, R.; Guerrero, C.; Mataix-Solera, J.; Arcenegui, V.; García-Orenes, F.; Mataix-Beneyto, J. Assessing air-drying and rewetting pre-treatment effect on some soil enzyme activities under Mediterranean conditions. Soil Biol. Biochem. 2006, 38, 2125-2134. [CrossRef]

44. Brockett, B.; Prescott, C.; Grayston, S. Soil moisture is the major factor influencing microbial community structure and enzyme activities across seven biogeoclimatic zones in western Canada. Soil Boil. Biochem. 2012, 44, 9-20. [CrossRef]

45. Schweinsberg-Mickan, M.S.Z.; Jörgensen, R.G.; Müller, T. Rhizodeposition: Its contribution to microbial growth and carbon and nitrogen turnover within the rhizosphere. J. Plant Nutr. Soil Sci. 2012, 175, 750-760. [CrossRef]

46. Carrillo, Y.; Dijkstra, F.A.; Pendall, E.; Lecain, D.; Tucker, C. Plant rhizosphere influence on microbial C metabolism: The role of elevated $\mathrm{CO}_{2}, \mathrm{~N}$ availability and root stoichiometry. Biogeochemistry 2014, 117, 229-240. [CrossRef]

47. Li, J.; Zheng, Y.; Yan, J.; Li, H.; He, J. Succession of plant and soil microbial communities with restoration of abandoned land in the Loess Plateau, China. J. Soil Sediment 2013, 13, 760-769. [CrossRef]

48. Susyan, E.A.; Wirth, S.; Ananyeva, N.D.; Stolnikova, E.V. Forest succession on abandoned arable soils in European Russia-Impacts on microbial biomass, fungal-bacterial ratio, and basal $\mathrm{CO}_{2}$ respiration activity. Eur. J. Soil Biol. 2011, 47, 169-174. [CrossRef]

49. Lupatini, M.; Jacques, R.J.S.; Antoniolli, Z.I.; Suleiman, A.K.A.; Fulthorpe, R.R.; Roesch, L.F.W. Land-use change and soil type are drivers of fungal and archaeal communities in the Pampa biome. World J. Microbiol. Biotechnol. 2013, 29, 223-233. [CrossRef] [PubMed]

50. Baldrian, P.; Trogl, J.; Frouz, J.; Snajdr, J.; Valaskova, V.; Merhautova, V.; Cajthaml, T.; Herinkova, J. Enzyme activities and microbial biomass in topsoil layer during spontaneous succession in spoil heaps after brown coal mining. Soil Boil. Biochem. 2008, 40, 2107-2115. [CrossRef]

51. Iii, E.W.H.; Frank, D.A. Can plants stimulate soil microbes and their own nutrient supply? Evidence from a grazing tolerant grass. Ecology 2001, 82, 2397-2402.

52. Girvan, M.S.; Bullimore, J.; Pretty, J.N.; Osborn, A.M.; Ball, A.S. Soil type is the primary determinant of the composition of the total and active bacterial communities in arable soils. Appl. Environ. Microbiol. 2003, 69, 1800-1809. [CrossRef] [PubMed]

53. Chen, M.M.; Zhu, Y.G.; Su, Y.H.; Chen, B.D.; Fu, B.J.; Marschner, P. Effects of soil moisture and plant interactions on the soil microbial community structure. Eur. J. Soil Biol. 2007, 43, 31-38. [CrossRef]

54. Singh, B.K.; Munro, S.; Potts, J.M.; Millard, P. Influence of grass species and soil type on rhizosphere microbial community structure in grassland soils. Appl. Soil Ecol. 2007, 36, 147-155. [CrossRef]

55. Yang, K.; Zhu, J. The effects of $\mathrm{N}$ and $\mathrm{P}$ additions on soil microbial properties in paired stands of temperate secondary forests and adjacent larch plantations in Northeast China. Soil Boil. Biochem. 2015, 90, 80-86. [CrossRef]

56. Larsen, J.; Jaramillolópez, P.; Nájerarincon, M.; Gonzálezesquivel, C.E. Biotic interactions in the rhizosphere in relation to plant and soil nutrient dynamics. J. Soil Sci. Plant Nutr. 2015, 15, 63-67. [CrossRef]

57. Ojuederie, O.B.; Babalola, O.O. Microbial and plant-assisted bioremediation of heavy metal polluted environments: A review. Int. J. Environ. Res. Public Health 2017, 14, 1504. [CrossRef] [PubMed]

58. Yao, M.; Rui, J.; Li, J.; Wang, J.; Cao, W.; Li, X. Soil bacterial community shifts driven by restoration time and steppe types in the degraded steppe of Inner Mongolia. Catena 2018, 165, 228-236. [CrossRef] 
59. Mai, K.; Biswas, B.; Smith, E.; Mahmud, S.A.; Hasan, N.A.; Khan, M.; Naidu, R.; Megharaj, M. Microbial diversity changes with rhizosphere and hydrocarbons in contrasting soils. Ecotox Environ. Safe 2018, 156, 434-442.

60. De Boer, T.E.; Taş, N.; Braster, M.; Temminghoff, E.J.; Röling, W.F.; Roelofs, D. The influence of long-term copper contaminated agricultural soil at different $\mathrm{pH}$ levels on microbial communities and springtail transcriptional regulation. Environ. Sci. Technol. 2012, 46, 60-68. [CrossRef] [PubMed]

61. Li, F.; Li, X.; Wu, P.; Chen, L.; Guo, B.; Qi, Z. Correlation between heavy metal pollution and basic properties of agricultural soils in Hainan province. Soils 2009, 41, 49-53.

62. Zhang, H.; Li, G.; Song, X.; Yang, D.; Li, Y.; Qiao, J.; Zhang, J.; Zhao, S. Changes in soil microbial functional diversity under different vegetation restoration patterns for Hulunbeier Sandy Land. Acta Ecol. Sin. 2013, 33, 38-44. [CrossRef]

63. Yan, Y.; Kuramae, E.E.; de Hollander, M.; Klinkhamer, P.G.; van Veen, J.A. Functional traits dominate the diversity-related selection of bacterial communities in the rhizosphere. ISME J. 2017, 11, 56-66. [CrossRef] [PubMed]

64. Holt, J.A. Grazing pressure and soil carbon, microbial biomass and enzyme activities in semi-arid northeastern Australia. Appl. Soil Ecol. 1997, 5, 143-149. [CrossRef]

65. Dise, N.B.; Matzner, E.; Forsius, M. Evaluation of organic horizon C:N ratio as an indicator of nitrate leaching in conifer forests across Europe. Environ. Pollut. 1998, 102, 453-456. [CrossRef]

66. Gundersen, P.; Callesen, I.; Vries, W.D. Nitrate leaching in forest ecosystems is related to forest floor C/N ratios. Environ. Pollut. 1998, 102, 403-407. [CrossRef]

67. Zhu, Q.; Xing, X.; Zhang, H.; An, S. Soil ecological stoichiometry under different vegetation area on loess hillygully region. Acta Ecol. Sin. 2013, 33, 4674-4682.

68. Iii, F.S.C.; Matson, P.A.; Mooney, H.A. Principles of Terrestrial Ecosystem Ecology; Springer: New York, NY, USA, 2011; pp. 369-397.

69. Zhang, Q.; Liu, B.; Lin, Y.; Shi, H.; Yang, S.; Zhou, X. The diversity of phospholipid fatty acid (PLFA) biomarker for the microbial community in soil. Acta Ecol. Sin. 2009, 29, 4127-4137.

70. Shentu, J.; He, Z.; Zeng, Y.; He, S.; Du, S.; Shen, D. Microbial biomass and PLFA profile changes in rhizosphere of Pakchoi (Brassica chinensis L.) as affected by external cadmium loading. Pedosphere 2014, 24, 553-562. [CrossRef]

71. Wu, X.; Li, Z.; Fu, B.; Zhou, W.; Liu, H.; Liu, G. Restoration of ecosystem carbon and nitrogen storage and microbial biomass after grazing exclusion in semi-arid grasslands of Inner Mongolia. Ecol. Eng. 2014, 73, 395-403. [CrossRef]

72. Chaparro, J.M.; Badri, D.V.; Vivanco, J.M. Rhizosphere microbiome assemblage is affected by plant development. ISME J. 2014, 8, 790-803. [CrossRef] [PubMed]

73. Su, Y.H.; Yang, X.Y. Interactions between selected PAHs and the microbial community in rhizosphere of a paddy soil. Sci. Total Environ. 2009, 407, 1027-1034. [CrossRef] [PubMed]

74. Han, X.M.; Wang, R.Q.; Liu, J.; Wang, M.C.; Zhou, J.; Guo, W.H. Effects of vegetation type on soil microbial community structure and catabolic diversity assessed by polyphasic methods in North China. J. Environ. Sci.-China 2007, 19, 1228-1234. [CrossRef]

75. Lambers, H.; Mougel, C.; Jaillard, B.; Hinsinger, P. Plant-microbe-soil interactions in the rhizosphere: An evolutionary perspective. Plant Soil 2009, 321, 83-115. [CrossRef]

(C) 2018 by the authors. Licensee MDPI, Basel, Switzerland. This article is an open access article distributed under the terms and conditions of the Creative Commons Attribution (CC BY) license (http://creativecommons.org/licenses/by/4.0/). 